\title{
GRADUATES AND STUDENTS OF THE RIGA POLYTECHNICUM / RIGA POLYTECHNIC INSTITUTE - PARTICIPANTS OF THE PROCLAMATION OF INDEPENDENT REPUBLIC OF LATVIA
}

\section{ALĪDA ZIGMUNDE*, ALVARS BALDIN̦Š \\ Riga Technical University}

Summary. In 2018, Latvia celebrates a hundred years since it became an independent state. One hundred years ago, on 18 November 1918, 38 members of the People's Council of Latvia (further in the text - the People's Council) took part in the proclamation of Latvia. None of them experienced the restoration of the Republic of Latvia, and most of them died before the end of the Second World War. There were seven graduates of the Riga Polytechnicum (RP) / Riga Polytechnic Institute (RPI) and one student who did not receive a diploma from the institute among the participants in the founding act of the Republic of Latvia. Of the seven graduates four suffered repressions in 1941 and were taken to Siberia, two after the Second World War went into exile, one died in 1924. Some of the participants of the Proclamation of the Republic of Latvia have left written testimonies about the beginnings of the state's foundation. All members of the People's Council were reputable Latvian citizens, some of them were awarded the Order of Three Stars for meritorious service to native land.

Keywords: Act of Proclamation of the Republic of Latvia, members of the Latvian People's Council, Riga Polytechnicum, Riga Polytechnic Institute, engineers.

\section{Engineers - participants of proclamation of the Republic of Latvia}

The Republic of Latvia was founded a week after the end of the First World War, but the idea of own country was already in place. There was

\footnotetext{
* Corresponding author.

E-mail: alida.zigmunde@rtu.lv
} 
a similar situation also in other East and Central European countries. The repressed European nations had become a political factor and had a common ground: «They were cultural nations with democratic principles, with the unconquerable will and self-determination to fight for their freedom. Therefore, ensuring the existence of all these new nations went hand in hand with the struggle for freedom [1].» Several dozen graduates and former students of RPI contributed to the defense of national independence in the struggle for freedom in Latvia, which lasted from 18 November 1918 until 11 August 1920, when the Latvian-Soviet Peace Treaty was signed. Many books, published articles and memoirs, and historians' studies were written about the events of those days. Less known are engineers, RPI graduates who have participated in the proclamation of the Republic of Latvia on 18 November 1918, because such research has not been carried out so far.

On 18 November 1918, at the Latvian National Theatre (then - the Riga Second City Theatre) the Republic of Latvia was proclaimed. A solemn meeting of 38 members of the People's Council from eight parties was held at the building designed by a graduate of the Department of Architecture (1881) of the Riga Polytechnicum Augusts Reinbergs (1860-1908). At this meeting an announcement was made that the power of sovereign state in Latvia is transferred to the People's Council. The People's Council was the interim legislator and from 17 November 1918, which continued the work that had been started by the «Latvian Provisional National Council», established on 29 November 1917 by the organisation of Latvian political parties of Valka city. Until 30 April 1920, the People's Council was the «temporary parliament» of the Republic of Latvia, the interim legislature. On 30 January 1918, the Latvian Provisional National Council adopted a resolution on the establishment of a united, independent and democratic Republic of Latvia [2]. Zigfrīds Anna Meierovics (1887-1925), a graduate of the Department of Commerce (1911) of Riga Polytechnic Institute (1911), was one of the founders of the political party «Latvian Farmers' Union» in 1917, and actively participated in the Council. Before the official proclamation of the Republic of Latvia, in the summer of 1918, Z. A. Meierovics went abroad in order to find the support of foreign governments for the new independent state. On 12 August, he arrived in London and on 23 October, he met Arthur James Balfour (1848-1930), the British Foreign Secretary. During the meeting, A. J. Balfour confirmed that the United Kingdom provisionally recognized the Latvian Provisional National Council as the Government of Latvia before the Paris Peace Conference ${ }^{1}$ [3]. On 11 November,

\footnotetext{
1 World War I conference held in Paris (1919-1920) to conclude peace treaties between
} the Allied Powers and the defeated Central Powers.
Graduates and Students of the Riga Polytechnicum / Riga Polytechnic Institute -

Participants of the Proclamation of Independent Republic of Latvia 
Z. A. Meierovics received a written confirmation from the British Foreign Office of Latvia's de facto recognition [4].

Most of people who founded the People's Council on 17 November 1918, also participated in the proclamation of the Republic of Latvia, including seven graduates from the Riga Polytechnicum / Riga Polytechnic Institute. They represented three political parties: the Latvian Farmers' Union (Jānis Vārsbergs, Vilis Gulbis, Oto Nonācs, Pēteris Muritis, Kārlis Vanags), Latvian Democratic Party (Mikelis Bružis) and the Latvian Independence Party (Spricis Paegle) [5]. The member of the Latvian Social Democratic Workers' Party Kārlis Kurševics, former RPI student, did not participate in the founding of the People's Council. The next day he came to the state proclamation.

Assessing the numerical composition of the members of the People's Council at the event of proclamation of the Republic of Latvia, it has to be concluded that $18 \%$ were the graduates of the RP / RPI, to add a chemistry student $K$. Kurševics, who was not a graduate yet - the total amount leads to $21 \%$. Who were these «polytechnicans» participating at the proclamation event?

Of the six Departments (at present - Faculties), which were established at the Riga Polytechnicum in the 1860s, three should be mentioned - Departments of Chemistry, Trade, and Agriculture, that were the Departments from which the "polytechnicans» participating at the event of the proclamation of the Republic of Latvia had graduated. Mikelis Bružis (1868-1941) who studied chemistry and graduated from the Department of Technical Chemistry of the Riga Polytechnicum, can be seen in the first row in the photograph of the event of proclamation of the Republic of Latvia on 18 November 1918 taken by Vilis Rìdzinieks [6]. After graduating from the Department of Technical Chemistry ${ }^{2}$ (1895), Mikelis Bružis worked for several years in Turkestan, returned to Riga in 1909 where he turned to construction and public activities. In 1920, M. Bružis was elected a member of the first Parliament of the Republic of Latvia - the Constitutional Assembly of Latvia (1920-1922). In addition, Mikelis Bružis served as Director-General of the Hipotēku (Mortgage) Bank (1924-1927) and Director of the Joint-Stock Company «Kieǵelis» («Brick») (1930-1936). In the 1930s he left active political life and began to write the book «Pasaules uzskats jeb cilvēks dabā, sabiedrība un mūžībā» («World Outlook, or a Human in Nature, Society and Eternity»), which was printed in 1936. After 76 years, it was reissued in 2002. During his free time engineer M. Bružis worked at the Riga Latvian Society and the Society for Promoting Latvian Art. On 14 June 1941, at the age of 73, he was deported to Solikamsk in Russia, where he departed this life in November of that year.

2 From 1896-Department of Chemistry. 
Mikelis Bružis' contemporary Spricis Paegle (1876-1962) also studied chemistry and in 1901 received an engineer's diploma at the Riga Polytechnic Institute. The two were members of the Latvian Student Corporation «Selonija». Spricis Paegle, who worked in the cement industry before the First World War, held the position of Minister of Trade and Industry (1918-1919) in the First Cabinet of Ministers of the Latvian Provisional Government. He was one of the founders of the Latvian Red Cross and a member of the Main Board (1921-1940), participated in the founding of the Latvian Red Cross School of Merciful Nursing (1920). After the Second World War, S. Paegle lived in Germany [7]. The engineer took active part in various societies, he was into collecting art and gardening. S. Paegle planted extensive alleys of apple trees, lime trees and maple trees, established a tree nursery at his homeland in Kalnabeites village (Sigulda municipality). There were about 10000 different trees and shrubs in the garden.

Figure 1. Spricis Paegle (around 1919) [8].

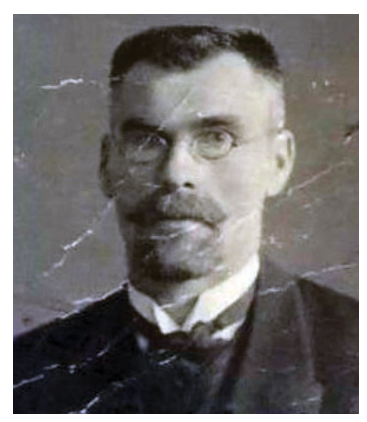

Spricis Paegle was one of 188 Latvian politicians and cultural workers who during the Second World War, on 17 March 1944, signed the Memorandum of the Latvian Central Council on the restoration of Latvia's independence and the establishment of the Latvian Government. The Memorandum on the Act of proclamation of the Republic of Latvia was signed by several RPI students - «polytechnicans» - and only two Spricis Paegle and Jānis Vārsbergs, were still living in Latvia th that time.

The agronomist, graduate of the Department of Agriculture (1908) of RPI, Jānis Vārsbergs (1879-1961), since the foundation of the University of Latvia in 1919 (until 1923 - the High School of Latvia), had worked as an Associate Professor and, since 1932, had been a Professor and Dean of the Faculty of Agriculture (1926-1928). From 1939 to 1944, Professor J. Vārsbergs worked at the Faculty of Agriculture at Jelgava Agriculture Academy. He specialized in «Swamp cultures and meadow management», went abroad on exchange of experience visits [9]. For many years the professor studied lawns, published the results of the research and promoted them at conferences and in lectures. Jānis Vārsbergs belonged to
Graduates and Students of the Riga Polytechnicum / Riga Polytechnic Institute -

Participants of the Proclamation of Independent Republic of Latvia 
Latvian Students' Corporation «Talavija». His life ended in Stockholm (Sweden) in May, 1961.

Among the participants of the event of proclamation of the Republic of Latvia, two more agronomists have to be mentioned. Vilis ${ }^{3}$ Gulbis (1890-1942), graduate of the Department of Agriculture (1914) of RPI started to work as an agronomist in Jaungulbene village. During the First World War in 1917 and 1918, he was Chairman of the Board of Governoate of Livonia and ensured that everyone was having enough bread and was not suffering from famine. Thanks to V. Gulbis, people of Governorate of Livonia did not experience such difficult times as other provinces of Governorate of Russian empire [10]. During the interwar period, his work was closely linked to the Government of the Republic of Latvia - V. Gulbis was elected to the 3rd and 4th Saeima, acted as the Minister of Agriculture (1928; 1930-1931; 1931-1933), Minister of Education (1933-1934), Minister of the Interior (1934-1939). Historian Rihards Treijs acknowledged that the post of the Minister of Education was «neither close to heart, nor liked» by the high-class agriculture professional V. Gulbis [11]. Perhaps this is why agronomist V. Gulbis was in this position for a much shorter time - less than a year, than in the position of the Minister of Ministry of Agriculture and Ministry of the Interior. In 1939, Vilis Gulbis became Director of the General Agriculture Bank. In 1940, he was arrested and deported to the Soviet Union. His life ended in Astrakhan prison in 1942. Vilis Gulbis had been a member of student corporation «Talavija» since study years.

The graduate of the Department of Agriculture (1915) of RPI, agronomist Pēteris Muritis (1891-1924) had a short life. After graduation he was Head of agricultural schools of Rüjiena and Valmiera cities, as well as a member of the Central Council of the Latvian Farmers' Union. He was shot during hunting and died at the age of 33 from the injury [12].

The graduate of the Department of Commerce of RPI, teacher, publicist and social worker, Oto Nonācs (1880-1942), was a founder of the Latvian National Council (1917), who, like other contemporaries, had a dream of an independent state of Latvia. The first Foreign Minister of Latvia, Zigfrìds Anna Meierovics (1887-1925), study mate of Oto Nonācs also worked in the Council. By the way, another Oto Nonācs study mate, the graduate of RPI (1911), Juhann (Johann) Kukk (1885-1942), was one of the compilers of the The Estonian Declaration of Independence, Minister of Finance (1918-1920), Minister of Trade and Industry (1920-1921) of Republic of Estonia and Head of State of Estonia (1922-1923).

Although the authors do not have any information on the relationship between $O$. Nonācs and J. Kukk, presumably they were very friendly. Possibly the Estonian study fellows encouraged 0 . Nonācs' special interest in Estonians and their history and culture, as he was a member and

3 In his documents - Vilis Gustavs. 
the chairman of the board of the Latvian-Estonian Association, and the Editor-in-Chief of the association's monthly journal (1935-1939) [13]. On 18 November 1918, Oto Nonācs participated in the event of proclamation of the Republic of Latvia [14]. He was Deputy of the 1st and 2nd Saeima, is the author of a number of books on the history of Latvia, including the establishment of the Republic of Latvia, about the restoration of Poland, about Sigulda and its surroundings, about a publicist and linguist Fricis Garais. O. Nonācs was a versatile personality, he was published in various newspapers, was an editor of the newspaper «Lïdums» (1915-1918) and Editor-in-Chief of the «Valdības Vēstnesis» («Government Messenger») (1919-1920). He experienced the repressions of the Soviet power, and his life ended in 1942 in Russia.

Figure 2. Oto Nonācs (around 1920s) [15].

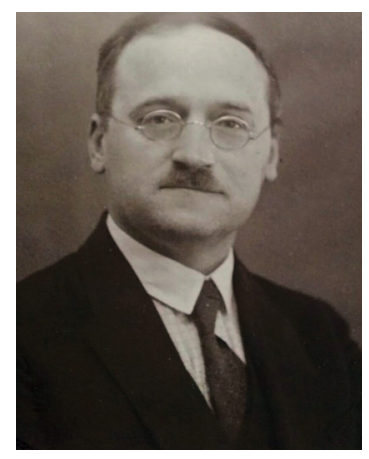

Bank employee Kārlis Vanags (1883-1942) graduated from the Department of Commerce of RPI in 1916. He served as Chief Executive Officer of the Bank of Latvia (1927-1940). He was suspended from the office during the Soviet time and was deported to Siberia in June 1941, where he was shot in the summer of 1942. K. Vanags was born in Smiltene municipality and where he spent his free time at the house named «Buliniı [16]. Both K. Vanags and O. Nonācs were members of student corporation «Talavija».

The life of the lawyer and public employee and participant of the event of proclamation of the Republic of Latvia, Kārlis Kurševics (1874-1938), is different from the above-mentioned life stories. He studied chemistry at RPI (1900-1902) and during study years he was in the revolutionary movement. He did not finish his studies in Riga and went to Switzerland and studied medicine and law at Zurich University. For a short time when back in Latvia, he wrote articles for the Liepāja newspaper «Dzīve» («Life») (1909-1910), was editor of the magazine «Vārpas» («Cereal Ear») (1908) and a member of editorial office of newspaper «Vidzemes Balss» («Vidzeme Voice») (1914). He published under a pseudonym Kārlis Liepa. Besides, Kārlis Kurševics is also known as a book publisher - he created 
the Latvian publishing house «Imanta» in St. Petersburg (1908-1909). He worked at the Moscow Latvian Culture Office, and after the revolutionary events in 1917, was a member of the Board of Vidzeme Land Council in Russia and, on his mission, travelled to St. Petersburg to demand the autonomy of Latvia [17]. Although K. Kurševics participated in the proclamation of the Republic of Latvia and supported the idea of the independent state of Latvia, after the Latvian War of Independence, he with his family moved to Soviet Russia in 1920 and joined the Communist Party. He is the only participant of the event of proclamation of the Republic of Latvia, who died (1938) in unjustified repressions during the Stalin's cult of personality in Russia [18].

\section{Evidences from former students of the Riga Polytechnicum / Riga Polytechnic Institute on the founding of the Republic of Latvia in 1918}

Today the events of 18 November 1918 are evidenced by the studies and documents of historians. RPI graduates have given a significant input by having written testimonies about the event. The founding of the Republic of Latvia was described by the graduates of the Riga Polytechnic Institute Spricis Paegle and Oto Nonācs. The book «Kã Latvijas valsts tapa» («How the State of the Republic of Latvia was Created»), published in 1923 by the chemist Spricis Paegle, tells not only about the establishment of the state but also the road to national independency - starting with the revolution of 1905, the years after the revolution, Latvians in the First World War, the idea of the independence of Latvia... At the end of the study, engineer $S$. Paegle described the time after the state was established until the meeting of the Constitutional Assembly of Latvia on 1 May 1920. The book has had two more editions - in 1939 and 1985, with the same number of pages (382) maintained in all three publications. The book by Spricis Paegle was based on personal experiences and observations and made it possible to reflect the history of the state of Latvia as objectively as it was already at that time, in 1923, that various people tried to distort it and even falsify for various purposes [19].

Ten years later, in 1933, the book «Pēc 18. novembra: Tautas Padomes loceklu memuāri» («After 18 November: Memoirs of Members of People's Council») by RPI graduate, teacher, journalist and social worker Oto Nonācs and RP graduate (1890), chemistry engineer Wilhelm Schreiner (1864-1936) was published. It should be noted that only Oto Nonācs was a member of the Latvian People's Council. Both engineers' memoirs were published in a single edition, but the book had two parts. One part is O. Nonācs' diary of the period from 29 December 1918 to 19 March 1919, 
when he left for Riga and was both in Liepajja and abroad, and another part was the memoirs of W. Schreiner on eleven months in Germany [20] - the government sent him to Berlin as the first envoy from Latvia.

Figure 3. The title page of S. Paegle's book «Kã Latvijas valsts tapa» («How the State of the Republic of Latvia was Created») (1939) [19].

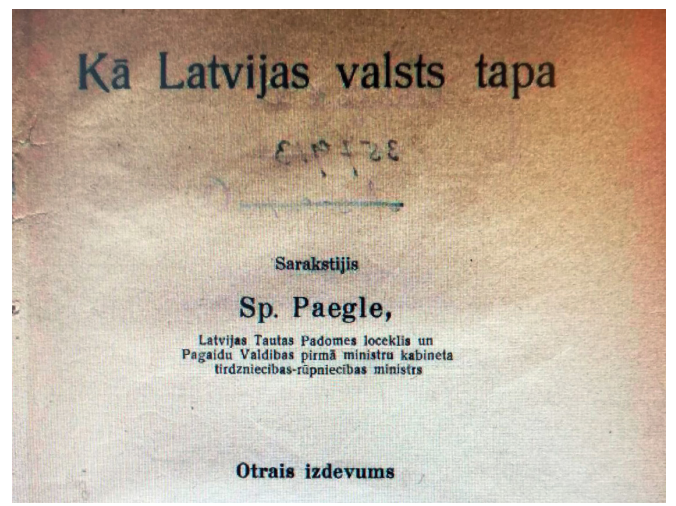

Graduates and Students of the Riga

Polytechnicum /

Riga Polytechnic Institute -

Participants of the Proclamation of Independent Republic of Latvia

The Provisional Government of Latvia had to start its activities under difficult conditions, which were briefly outlined by 0 . Nonācs in the book: «The epoch after 18 November was the most muddled time in the history of Latvia, when the achievement of 18 November had to stand the most difficult. The proclamation of the state was a signal for all open and secret enemies of the Latvian people to rebel against the ultimate goal of the people's efforts. The already shaken occupation power sought and found support in the bolshevism, and both of these completely opposite powers got along in their common negative objective - to destroy the State of Latvia [21].»

Figure 4. Title page of the book «Pēc 18. novembra: Tautas Padomes locekl̦ memuāri» («After 18 November: Memoirs of Members of People's Council») by RP / RPI graduates $O$. Nonācs and W. Schreiner (1933) [21].

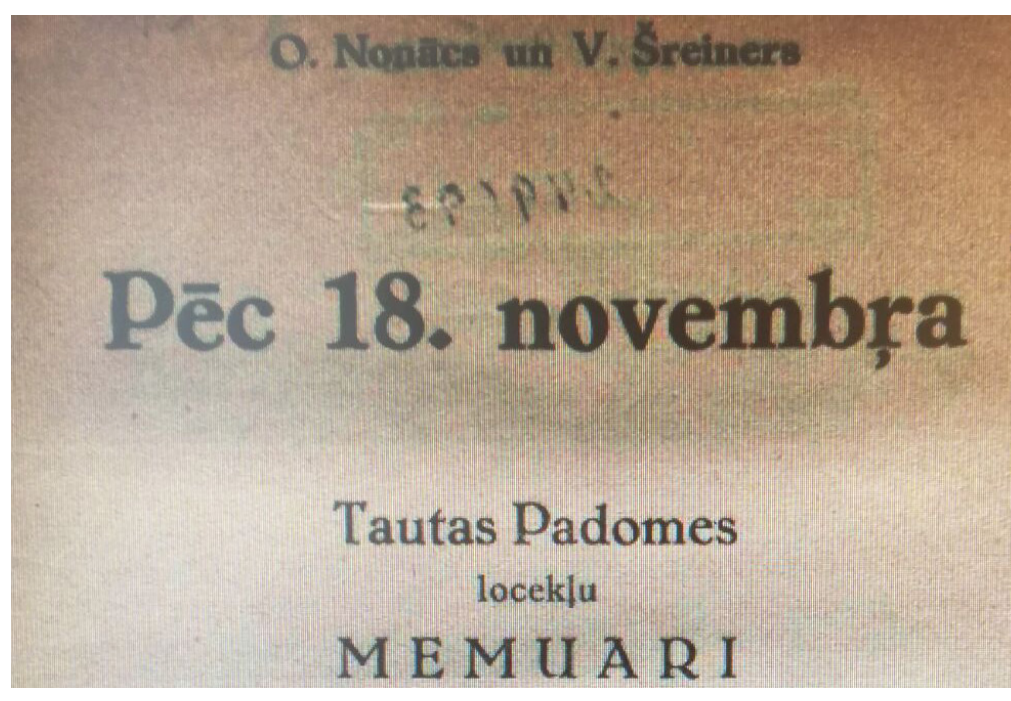


The second author of the book, engineer W. Schreiner, as diplomatic agent of the Latvian Provisional Government, arrived in Berlin in the summer of 1919, and did a remarkable work in winning the favour of the German Government for Latvia. He arranged the representation of Latvia and «on 18 November 1919 organized the first Latvian statehood celebration in Berlin [22].» It should be noted that W. Schreiner was German nationality and belonged to the Baltic-Germans who were loyal to the creation and existence of Latvia's statehood. This is evidenced by his diplomatic work in Berlin and later also in Prague and Czechoslovakia. It should be added that his son-in-law, Lieutenant Colonel Fridrihs ZuteZutis (1886-1959), studied in the Department of Mechanical Engineering (1915/1916) of RPI, fought for Latvia's independence, and was awarded with the Order of Lāčplēsis [23].

There were many people present in the hall during the proclamation of the Republic of Latvia, but there was no list of those being present. It is well known that on 18 November 1918, a former student of the Department of Engineering and Chemistry of RPI, Fridrihs Zommers (Vasarietis from 1940; 1881-1973), was also present at the National Theatre House during the proclamation event and was «responsible for order and security during the proclamation event [24].» An entrepreneur, diplomat, lieutenant colonel F. Vasarietis wrote about his memories of the events before the proclamation of the Republic of Latvia - on 17 November 1918, when representatives of Latvian political parties agreed to proclaim the independence of Latvia next day. The memories of $F$. Vasarietis were written in Riga on March 1965. During the Soviet era, he managed to avoid repressions, and his memories did not get into the hands of repressive institutions. Fridrihs Vasarietis was awarded with the Order of Lä̌rplessis and Order of the Three Stars.

Many former students and graduates of the RP / RPI, including the participants of the event of proclamation of the Republic of Latvia such as Mikelis Bružis, Oto Nonācs, Spricis Paegle, Jānis Vārsbergs were awarded with the Order of Three Stars for meritorious service to native land, but Vilis Gulbis was awarded with the Order Three Stars of First, Second, Third and Fourth Class. In celebration of the centenary of Latvia participants of the event of proclamation of the Republic of Latvia are honoured as well. For example, with the support of the State Culture Capital Foundation, Sigulda District Municipality and the Institute of Literature, Folklore and Art of the University of Latvia, documentary film about one of them - Spricis Paegle «Spricis Paegle. Atminas» («Spricis Paegle. Memories») was made. It reveals the life of the Latvian businessman, politician and public servant in Rüjiena, Rìga, Sigulda, and Insula (Germany) - where he spent his last years in the house for the elderly [25]. 


\section{LIST OF SOURCES AND LITERATURE}

[1] Šilde, Ā. Pirmā Republika: esejas par Latvijas valsti. Rīga: Elpa, 1993, 182. lpp.

[2] Šilde, Ā. Pirmā Republika: esejas par Latvijas valsti. Rīga: Elpa, 1993, 161.-168. lpp.

[3] Līgotṇu, J. Zigfrīds Meierovics: mūžs, darbs, liktenis. Rīga: Valters un Rapa, 2000, 75. lpp.

[4] Lerhis, A. Latvijas Republikas ārlietu dienests, 1918-1941. Rīga: Latvijas vēstures institūta apgāds, 2005, 56. lpp.

[5] Latvijas Republikas Pagaidu valdības sēžu protokolos, notikumos, atmiñās, 1918-1920: veltījums Latvijas Republikas pasludināšanas 95. gadadienai. Rīga: Latvijas Vēstnesis, 2013, 72. lpp.

[6] Grosvalds, I. Inženieris kīmikis Mikelis Bružs un fizikālkīmikis profesors Boriss Bružs dzīvē un darbā. RTU zinātniskie raksti. Humanitārās un sociālās zinātnes. Rīga: RTU, 2016/26, 37. lpp.

[7] Ar parakstu par Latviju. Latvijas Centrālās Padomes Memoranda parakstītāju biogrāfijas. Rīga: Latvijas Kara muzejs, 2014, 66. lpp.

[8] Spriča Paegles Latvijas Republikas pase. Latvijas Valsts vēstures arhīvs (turpmāk - LVVA) 2996. f., 15. apr., 905. l., 1. lp.

[9] Latvijas Universitāte, 1919 - 1929. Rīga: LU, 1929, 319.-320. lpp.

[10] Vispārējās Lauksaimniecības bankas direktors agronoms Vilis Gulbis. Brīvā Zeme, 1939, No. 14, 1.lpp.

[11] Treijs, R. Valdība un zinātne gadu ritumā. Zinātnes Vēstnesis, 1999, No. 19, 4. lpp.

[12] Rauzāns, G. Jaunas sejas senā fotogrāfijā. Latvijas Vēstnesis, 1998, No. 212/213, 13. lpp.

[13] Latvijas-Igaunijas biedrības pilnsapulču protokoli. LVVA 3724. f., 1. apr., 4774. 1., 10. lp.

[14] Nonācs, O., Šreiners, V. Pēc 18. novembra: Tautas Padomes locekḷu memuāri. Rīga: Valters un Rapa, 1933, 178 lpp.

[15] Oto Nonāca Latvijas Republikas pase. LVVA 2996. f., 13. apr., 6603. l., 5. lpp.

[16] Latvijas Bankas galvenais direktors K. Vanags - Smiltenes Konzumbiedrības biedrs. Smiltenes Zingas, 1937, No. 44, 1. lpp.

[17] Limane, L. Kurševičs Kārlis http://lgdb.lnb.lv/index/person/1858/ [skatīts 24.06.2018].

[18] Rauzāns, G. Jaunas sejas senā fotogrāfijā. Latvijas Vēstnesis, 1998, No. 212/213, 13. lpp.

[19] Paegle, S. Kā Latvijas valsts tapa. Rīgā: autora apgādībā, 1923, 7. lpp.

[20] Nonācs, O., Šreiners, V. Pēc 18. novembra : Tautas Padomes locekḷu memuāri. Rīga: Valters un Rapa, 1933, 193. lpp.

[21] Nonācs, O., Šreiners, V. Pēc 18. novembra : Tautas Padomes locekḷ memuāri. Rīga: Valters un Rapa, 1933, 4. lpp.

[22] No Keizara dambja līdz Eiropas centram. Latvija, 1968, No. 45, 1. lpp. 
[23] Lāčplēša Kara ordeṇa kavalieri. Rīga: Latvijas Valsts vēstures arhīva, 1995, 589. lpp.

[24] Vasarietis (Zommers), F. Patstāvīga Latvijas valsts piedzima 1918. gada 17. novembrī. Padomju Jaunatne, 1989, No. 220, 2. lpp.

[25] Tapis videostāsts par Sprici Paegli

http://lfk.lv/Tapis-videostasts-par-Sprici-Paegli [skatīts 24.06.2018].

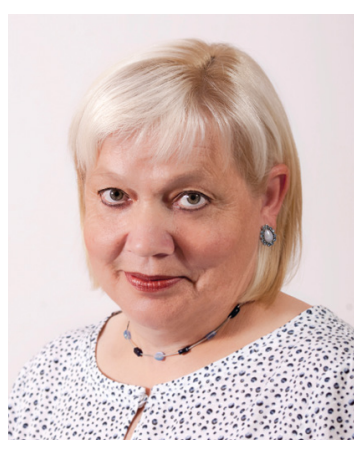

ALĪDA ZIGMUNDE, Dr. paed., has been a Specialist at the Museum of Riga Technical University since 1989. From 2007 to 2015, she was a Senior Researcher. She is currently a Professor at the Institute for Humanities and Head of the Department for Historic Research and Scientific Publications of the RTU Research Centre for Engineering History. Her main academic interests include the history of pedagogy in Europe, the history of the institutions of education and of private schools, and the history of pedagogy of universities, history of engineering sciences and universities.

Address: 1 Kronvalda Boulevard, Riga, LV1010, Latvia

Phone: +37129869642

E-mail: alida.zigmunde@rtu.lv

ALVARS BALDIN̦Š, Dr. phil., Dr. sc. pol. His major fields of study are adult education, theories of didactics and social pedagogy. He was an Associate Professor and Head of the Institute of Humanities of Riga Technical University (until August 2018). Previously he was Head of the Institute of Adult Pedagogical Education of the University of Latvia (1992-2001).

Address: 1 Kronvalda Boulevard, Riga, LV-1010, Latvia

Phone: +371 29226779

E-mail: alvars.baldins@inbox.lv

Alīda Zigmunde, Alvars Baldiņš

\section{Rīgas Politehnikuma / Rīgas Politehniskā institūta studenti un absolventi - Latvijas Republikas pasludināšanas akta dalībnieki}

2018. gadā atzīmē Latvijas Republikas dibināšanas simtgadi. Pirms simts gadiem, 1918. gada 18. novembrī, Latvijas valsts dibināšanas aktā piedalījās 38 Latvijas Tautas padomes (turpmāk - Tautas padome) locekḷi. Neviens no viṇiem nepieredzēja Latvijas Republikas atjaunošanu, un vairumam no vinniem mūžs aprāvās pirms Otrā pasaules kara beigām. Latvijas Republikas dibināšanas akta dalībnieku vidū bija septiṇi Rīgas Politehnikuma / Rīgas Politehniskā institūta absolventi un viens augstskolas diplomu neieguvis students. No septiniem absolventiem četri 1941. gadā piedzīvoja represijas un tika aizvesti uz Sibīriju, divi pēc Otrā pasaules kara devās trimdā, viens bija miris spēka gados 1924. gadā. Daḷa no Latvijas Republikas proklamēšanas akta dalībniekiem atstājuši rakstītas liecības par valsts tapšanas pirmsākumiem. Visi Tautas padomes 
locekḷi bija cienījami Latvijas pavalstnieki, dạ̣a no viṇiem par nopelniem Tēvijas labā apbalvoti ar Triju Zvaigžņu ordeni.

Atslēgas vārdi: Latvijas Republikas pasludināšanas akts, Latvijas Tautas padomes locekḷi, Rīgas Politehnikums, Rīgas Politehniskais institūts, inženieri.

\section{Алида Зигмунде, Алварс Балдыньш}

Студенты и выпускники Рижского политехникума /

Рижского политехнического института - участники акта провозглашения Латвийской Республики

В 2018 году празднуется столетие со дня провозглашения Латвийской республики. Сто лет тому назад 18 ноября 1918 года в акте провозглашения Латвийского государства участвовало 38 членов Народного совета Латвии (далее - Народный совет). Никто из них не дожил до восстановления Латвийской Республики, большинство из них скончалось до конца Второй мировой войны. Среди участников акта провозглашения Латвийской Республики было семеро выпускников Рижского политехникума (РП)/Рижского политехнического института (РПИ) и один, не завершивший учебу, студент. Четверо из семи выпускников в 1941 году пострадали в ходе репрессий и были сосланы в Сибирь, двое после Второй мировой войны отправились в изгнание, один скончался в расцвете сил в 1924 году. Часть участников акта прокламации Латвийской Республики оставили письменные свидетельства о зарождении нового государства. Все участники Народного совета были уважаемыми гражданами Латвии, часть из них за заслуги перед Отечеством была награждена орденом Трех звезд.

Ключевые слова: акт провозглашения Латвийской Республики, Члены Народного совета Латвии, Рижский политехникум, Рижский политехнический институт, инженеры.
Graduates and Students of the Riga

Polytechnicum /

Riga Polytechnic Institute -

Participants of the Proclamation of Independent Republic of Latvia 